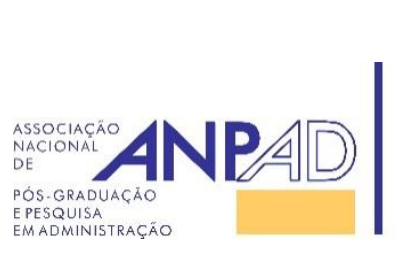

Disponível em

http://www.anpad.org.br/rac

RAC, Rio de Janeiro, v. 20, n. 6, art. 2, pp. 673-692, Nov./Dez. 2016

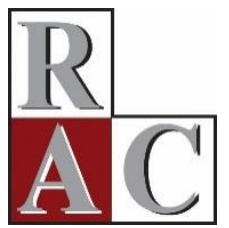

$(c)$ EY

\title{
The Influence of Power and Individualism-Collectivism on Negotiation Initiation
}

\author{
Roger Volkema ${ }^{1}$ \\ Ilias Kapoutsis ${ }^{2}$ \\ Ana Bon ${ }^{1}$ \\ José Ricardo Almeida ${ }^{3}$ \\ Pontifícia Universidade Católica do Rio de Janeiro ${ }^{1}$ \\ Athens University of Economics and Business ${ }^{2}$ \\ Universidade Federal da Bahia ${ }^{3}$
}

Artigo recebido em 01.04.2015. Última versão recebida em 10.07.2015. Aprovado em 16.07.2015. Publicado online em 31.05.2016. 


\title{
Resumo
}

Negociação é um processo essencial na área de negócios e seu início pode afetar o desenrolar de todo o processo. Embora oportunidades possam ser perdidas quando uma ou mais partes fracassam no começo de uma negociação, essa fase tem sido pouco explorada pelas pesquisas até há bem pouco tempo. Este artigo relata os resultados de um estudo de negociações que examina os efeitos de fatores situacionais/contextuais e culturais no processo de iniciação (acionando a outra parte, fazendo uma solicitação, otimizando a solicitação), concentrando-se especificamente quanto ao poder relativo de barganha (fator situacional) e individualismo-coletivismo. Encontraram-se evidências de que um alto poder de barganha aumenta a probabilidade da intenção de iniciar uma negociação em geral, e, mais especificamente, de fazer uma solicitação e otimizar essa solicitação. Os fatores culturais individualismo e coletivismo também apresentaram evidências que afetam a iniciação de uma negociação: individualistas tiveram maior probabilidade de iniciar uma negociação que os coletivistas, sendo esse efeito aumentado para aqueles individualistas com alto poder relativo de barganha. As implicações práticas e teóricas dos resultados encontrados são discutidas e sugestões de pesquisas futuras são apresentadas.

Palavras-chave: negociação; iniciação; poder; cultura; individualismo-coletivismo.

\begin{abstract}
Negotiation is an essential business process, with the initiation of a negotiation likely to affect how the process unfolds. Despite the fact that opportunities are often lost when one or more parties fail to initiate, initiation has until recently been overlooked in negotiation process models and research. This paper reports findings from a study that examines the effects situational/contextual factors and culture have on the initiation process (engaging a prospective counterpart, making a request, and optimizing that request), focusing specifically on relative bargaining power (a situational factor) and individualism-collectivism. Higher bargaining power was found to increase the likelihood of initiation intentionality in general as well as the requesting and optimizing phases more specifically. In addition, individualism/collectivism was also found to affect initiation, with individualists more likely than collectivists to initiate a negotiation. Further, this effect was enhanced when individualists had high relative bargaining power. The theoretical and practical implications of these findings are discussed, with suggestions for future research.
\end{abstract}

Key words: negotiation; initiation; power; culture; individualism-collectivism. 


\section{Introduction}

Negotiation is an interpersonal decision-making process that individuals undertake when they cannot achieve their objectives single-handedly (Thompson, 2012). A ubiquitous process in both personal and profession settings, negotiation is generally viewed as central to organizational planning, problem-solving, and decision-making, and one of the key skills of successful managers (Lax \& Sebenius, 1986; Mintzberg, 1973; Mnookin \& Susskind, 1999).

As reported in many disciplines, the early stages of a process often play a crucial role in how subsequent stages unfold. In group/team development, for example, how the group is formed will affect its subsequent performance as a collective body (Furst, Reeves, Rosen, \& Blackburn, 2004; Tuckman, 1965). Similarly, the initial stages of planning and problem-solving (e.g., how a problem is defined, as a human resources problem versus as a technical problem) often will affect the later stages of these processes (e.g., how the problem is solved) (Mitroff \& Silver, 2009; Nutt, 1984).

The same can be said for negotiation, which requires at least one of the parties to initiate the process (engage a counterpart, share information, make a request). Too often, however, individuals fail to take advantage of a negotiating opportunity due to lack of awareness or motivation (Bear, 2011; Kong, Tuncel, \& McLean Parks, 2011; Miles, 2010). This failure to initiate can prove costly to all parties, as when chronic organizational problems with known solutions go unsolved, opportunities for joint ventures dissipate for lack of a proposal, and talented employees depart without any warning (Huppertz, 2003). Indeed, the Abilene Paradox illustrates extreme cases of this social phenomenon, where no one acts in his/her best interests to raise issues or declare preferences despite the fact that all are in silent agreement regarding their desire for the same outcome (Harvey, Buckley, Novicevic, \& Halbesleben, 2004).

Despite the importance of negotiation to organizational decision-making and the necessary role of initiation, many studies of negotiation have employed research designs that assume the parties are already at the table, thereby overlooking this critical stage of the process. Instead, much of the research on negotiation has been concerned with reaching agreements, as suggested by the title of one of the most enduring books in the field of negotiation, Getting to Yes (Fisher \& Ury, 1981). This research has focused on the types of outcomes or agreements pursued (e.g., distributive vs. integrative), as well as the factors that might influence the achievement of those outcomes (styles, tactics, behaviors, etc.) (Bazerman, Curhan, Moore, \& Valley, 2000; Lewicki, Weiss, \& Lewin, 1992; Tsay \& Bazerman, 2009).

Oversight of initiation's importance has begun to change, however, due in part to two apparently independent events - the globalization of commercial markets, and the emergence of women in the workforce. The former has forced many Western nations to recognize the emphasis that much of the rest of the world places on the initial stages of negotiation (relational development, in particular) (Gelfand \& Brett, 2004; Requejo \& Graham, 2008), while the latter has brought attention to the differences in how men and women perceive negotiating, which has implications for if, when, and how a negotiation is pursued (Bowles, Babcock, \& Lai, 2007; Gerhart \& Rynes, 1991; Small, Gelfand, Babcok, \& Gettman, 2007).

As these phenomena suggest, there are several factors that can affect the negotiation process generally and initiation specifically, factors which fall into either of two broad and oft-cited categories - individual attributes and situational characteristics (Bazerman et al., 2000; Lewicki, Barry, \& Saunders, 2010; Volkema \& Rivers, 2012). Of these two categories, the former has been the focus of attention for a number of studies on initiation intentions and behavior, including demographic factors (gender, age) and personality (e.g., Machiavellianism, risk propensity, self-efficacy) (Bodey \& Grace, 2007; Thøgersen, Juhl, \& Poulsen, 2009; Volkema, Kapoutsis, \& Nikolopoulos, 2013).

Though studied less frequently in this context, culture is typically included in the individual attributes category and also can influence an individual's beliefs regarding the appropriateness of pursuing a negotiation. Like personality, culture - the shared beliefs of a group of individuals, such as 
the importance placed on showing respect towards and concern for others - is an enduring characteristic; even when individuals are relocated to another culture, their attitudes or beliefs can persist (Gelfand \& Brett, 2004). To date, however, the effects of culture on initiation behavior have largely been limited to studies of consumer complaints ( $c f$. Chelminski \& Coulter, 2007; Liu, Furrer, \& Sudharshan, 2001). Further, initiation has generally been viewed as a singular binary event (asking, or not asking) rather than treating the process as a natural sequence of decisions (e.g., the decision to engage a prospective counterpart or not, the decision to make a request or not, and the decision regarding the nature/amount of the request).

In contrast to individual attributes, situational characteristics are perhaps the more malleable and influential of the two broad categories, capable of moderating the effects of personality/demographic factors (Small et al., 2007). As Bazerman, Curhan, Moore, and Valley (2000) argue in their review of research on negotiation, "slight changes in situational features swamp these [individual difference] effects" (p. 281). Like culture, the influence of context/situation on initiation behavior has received limited empirical investigation, with some focus on the demeanor or reputation of a prospective counterpart, the venue of a negotiation (public, private), the importance of the stakes, and perceived alternatives to negotiating with a counterpart (Chebat, Davidow, \& Codjovi, 2005; Magee, Galinsky, \& Gruenfeld, 2007; Thøgersen et al., 2009). As with culture, initiation has generally been operationalized as a single decision rather than as a sequence of decisional events.

This paper reports on a study of the effects of two factors on the initiation process context/situation and culture - focusing specifically on the relative bargaining power of the initiator visà-vis his or her counterpart and a dimension of culture frequently linked to negotiating behavior, individualism-collectivism. Using a pair of business negotiation scenarios suggested by Ames (2008), the effects of these two factors on initiation overall as well as on three stages of the initiation process (engaging, requesting, and optimizing) are examined. The implications of the main and interactive effects of these factors are discussed with respect to practitioner behavior and future research on initiation behavior.

\section{Theory and Hypotheses}

Much like negotiation in general (Tsay \& Bazerman, 2009), the initiation stage of negotiation can be described as a multi-phase decision-making process, including engaging, requesting, and optimizing (Volkema et al., 2013). An individual must first decide whether or not to engage (approach, contact) a prospective counterpart. In most cases, the lack of engagement at least postpones if not eliminates the opportunity to negotiate. This can have obvious implications for the individual failing to take the initiative, but it also can affect other parties that could potentially benefit from the negotiation (e.g., a supplier that has additional delivery capacity to augment a shipment, a competitor that would benefit from a joint venture).

In the event of engagement, an individual may or may not choose to make a request. The decision not to ask immediately (e.g., to join the conversation but remain silent with respect to personal needs or desires) leaves open, however, the possibility that one's counterpart will raise the issue of interest. If a request is made, an individual must decide how to frame that request and how much to request (Volkema, 2009). More specifically, should the individual ask for exactly what he/she wants, more than is desired (an exaggerated request), or less than is desired (to reduce the chances of a counterpart aborting the negotiation prematurely, or introducing or re-introducing other issues)? While making an exaggerated or extreme request can increase one's outcome (Miles \& Clenney, 2012), it is not a guarantee of success, particularly in the context of uncertain or unavailable alternatives.

To understand what can trigger or inhibit these phases of initiation (engaging, requesting, optimizing), we turn to research on the broader process of negotiation. Among the factors that have been found to influence the negotiation process, social power is a situational factor that has been studied 
extensively. Operationalized as resource dependency, researchers have found social or bargaining power to influence many facets of negotiation, including information exchange, tactics, concessions, and outcomes (for reviews, see Bacharach \& Lawler, 1981; Kramer \& Messick, 1995; Lewicki, Barry, \& Saunders, 2010).

Power is ever-present in organizations, rooted in positional (e.g., legitimate authority) or personal (e.g., expertise, charisma) sources yet a function of individual perceptions (French \& Raven, 1959; Pfeffer, 1983). As a consequence of its perceptual nature, power is a dynamic phenomenon, capable of changing as the beliefs or expectations about a party or situation are altered (often through subtle behavioral indicators, such as in whose office the negotiation is held, whether or not one party has to wait to see the other, etc.). These characteristics make power an important factor in understanding negotiations generally and initiation specifically, as the latter will be determined by an individual's perceived dependence on a prospective counterpart to achieve his/her objectives (Thompson, 2012).

According to Keltner, Gruenfeld, and Anderson (2003), power can influence two fundamental behavior systems that have implications for the initiation process - the behavioral approach system (BAS) and the behavioral inhibition system (BIS). While the former is concerned with scanning one's environment for potential rewards, the latter is alert to potential threats or costs of action or inaction. Keltner et al. (2003) suggest that perceived relative power enhances an individual's BAS while diminishing his or her BIS. Thus, having relative bargaining power would likely increase an individual's attention to the potential rewards associated with initiating a negotiation in pursuit of his/her personal objectives, which might include engaging a counterpart, making a request, and optimizing that request.

Galinsky, Gruenfeld, and Magee (2003) concur, arguing that there is an inverse relationship between power and an individual's sensitivity to social norms, standards, and threats. Therefore, with more power comes less adherence to norms and standards, along with a greater likelihood of taking action in pursuit of one's goals. Individuals lacking bargaining power, on the other hand, are more inclined to choose avoidance behaviors, primarily over concern with their counterparts' potential punitive capabilities (De Dreu, Giebels, \& Van de Vliert, 1998).

Magee, Galinsky, and Gruenfeld (2007), in a series of experiments, found a positive relationship between an individual's power and his/her likelihood of initiating a negotiation, making the opening arguments in a debate, expressing his/her intention of making the first offer, and making the first offer. Indeed, Galinsky, Magee, Inesi, and Gruenfeld (2006) contend that power reduces the tendency to consider another party's views and feelings, which suggests that having power might not only promote engaging a negotiating counterpart and making a request, but optimizing that request as well. Therefore,

Hypothesis 1: The more relative bargaining power a negotiator has in a situation, the greater his or her likelihood of initiating a negotiation (engaging, requesting, optimizing).

Culture represents the characteristics of a particular group of people, as defined by their shared beliefs, attitudes, norms, and behaviors, and as reflected in the group's institutional structures (social, political, economic, religious) that reinforce social interactions within the group (Adair \& Brett, 2004). In an era of heightened international trade, culture has become a central issue in understanding crosscultural communications and negotiator efficacy. Culture has been shown, in negotiation research, to be associated with level of formality, the importance given to goal/task accomplishment versus relational development, sensitivity to time and deadlines, the method of analysis and argumentation, degree of directness, and individual versus team structure (Curhan, Elfenbein, \& Xu, 2006; Gelfand \& Brett, 2004; Requejo \& Graham, 2008; Salacuse, 1999). It has also been suggested as a factor that could influence initiation behavior (Volkema, 2012).

There have been a number of scholars who have sought to articulate the dimensions of culture, including Triandis (1989), Schwartz (1992), Hofstede (1997), and House, Hanges, Javidan, Dorfman, and Gupta (2004). Hofstede's seminal work, oft-cited and the basis for other models and studies (e.g., House, Hanges, Javidan, Dorfman, \& Gupta, 2004), originally focused on four dimensions of culture: power distance, individualism-collectivism, uncertainty avoidance, and masculinity-femininity. While 
Volkema (2012) argues that each of these cultural dimensions could affect the initiation process, there is an obvious overlap between power distance and the situational power mentioned above. Uncertainty avoidance is related to risk propensity, which has been examined in prior research (Kapoutsis, Volkema, \& Nikolopoulos, 2013), while masculinity-femininity has a gender component that also has been studied with respect to initiation ( $c f$. Bear, 2011; Bowles et al., 2007). Although individualism-collectivism is the most-cited cultural dimension in studies of negotiation (Bazerman et al., 2000), it has gone unexamined as a predictor of initiation behavior.

In general, individual rights, achievement, and recognition are highly valued in an individualist culture (such as those typically found in the countries of North America and Northwestern Europe), whereas harmony and cooperation within the family, organization, and community are central in collectivist cultures (Gelfand \& Realo, 1999). In addition to affecting the negotiation process generally, individualism-collectivism can influence the timing and manner in which favors, requests, offers, and complaints are initiated. For example, one of the characteristics of individualists is that they often view negotiations from a fixed-pie (distributive) perspective, which can affect how they perceive the appropriateness of various behaviors. With an orientation towards self, individualists typically show less concern for the consequences of their actions to other parties (Gelfand \& Christakopoulou, 1999). Collectivists, in contrast, are concerned with maintaining relationships. As a result, they are less likely to take actions that could be detrimental to self-face (i.e., self identity, respect) or other-face (i.e., a prospective counterpart's public identity). This includes the decision regarding how to engage a counterpart, preferring an indirect approach (e.g., initiating through an established network, such as a common acquaintance) over a direct approach like cold-calling (which might be favored more by an individualist) (Lee, Yang, \& Graham, 2006).

Striving to maintain harmony, people from collectivist cultures often lean more towards avoidance behavior (Oetzel, Garcia, \& Ting-Toomey, 2008; Oetzel \& Ting-Toomey, 2003). In a study comparing individuals from regions typically viewed as more collectivist versus regions viewed as having an individualist orientation, for example, Taylor et al. (2004) found that participants from the former group were less likely than participants from latter to seek support during periods of stress, ostensibly due to concerns over disturbing group harmony, losing face, receiving criticism, and/or making the situation worse. Similarly, a study of organizational newcomer behavior by Morrison, Chen, and Salgado (2004) found that newcomers from a region viewed as having a predominantly collectivist orientation were less likely than newcomers from an individualist culture to request a supervisor's feedback as a means of reducing uncertainty and managing performance.

Research on complaining behavior also suggests potential differences in initiation due to this cultural dimension. Liu, Furrer, and Sudharshan (2001) found that customers from more individualistic cultures were more likely to take action when they received poor service quality (i.e., engage and request/demand). Similarly, Chelminski and Coulter (2007), in a study exploring consumer behavior in individualist and collectivist cultures, reported a positive effect of individualism on propensity to voice - the inclination to complain directly to a firm or salesperson. They also showed that self-confidence mediated the relationship between individualism and propensity to voice. Given this theoretical foundation and the related empirical support, we propose the following for the initiation process:

Hypothesis 2: The more individualist a negotiator, the greater his or her likelihood of initiating a negotiation (engaging, requesting, optimizing).

As noted, collectivists lean towards maintaining relational harmony, often to the point of avoiding any behaviors that might be viewed as self-oriented or socially awkward. In some cases, avoidance will extend beyond avoiding issues to eschewing encounters. Individualists, on the other hand, are more concerned with self, and generally more willing to employ distributive means to satisfy their selfinterests. The recognition of power as a tool that might enhance an individualist's chances of achieving personal goals suggests that individualists with high relative bargaining power would be more willing than negotiators with low power to initiate a negotiation. In particular, we might expect individualists with power to not only make a request, but to optimize that request as well. Therefore, 
Hypothesis 3: An individualist negotiator with high relative bargaining power will have a greater likelihood of initiating a negotiation (engaging, requesting, optimizing) than will a collectivist negotiator with high relative bargaining power.

\section{Method}

\section{Participants}

One hundred twenty-two Brazilian professionals from a cross-section of organizations participated in this study, all of whom spoke English (the language of the study). A Brazilian sample was selected because of its individualist-collectivist composition: Hofstede (2001) found Brazil to have a moderately collectivist culture, while House et al. (2004) reported an individualist orientation with respect to practices (as is) but a collectivist orientation for values (should be). All of the participants in this study were born in Brazil and considered themselves Brazilians. Sixty-four percent of the participants were males, and the mean age of the participants was $38.13(\mathrm{SD}=10.72)$.

\section{Procedure}

Each participant in the experiment was presented with two scenarios - a salary negotiation and a work assignment involving a freelancer - and asked to rank-order four alternatives regarding how they would respond in each case. The scenarios (shown in Appendix) were modifications of business situations suggested by Ames (2008) which had been used successfully in other studies (e.g., Kapoutsis et al., 2013). The four alternatives for each scenario represented different levels of intentions to initiate behavior. From lowest to highest level of initiation, these included: (a) not engaging a prospective counterpart, (b) engaging a prospective counterpart but not making a request, (c) engaging a prospective counterpart and making a sub-optimal request, and (d) engaging a prospective counterpart and making an optimal request. For each scenario, the alternatives were presented in a random order. Finally, each participant was asked to complete a post-experiment questionnaire that included questions regarding individualism-collectivism (described below), along with questions about personal demographics (e.g., age, gender). To reduce the likelihood of common method bias (i.e., threats to construct validity, which can be found in studies employing multiple self-report instruments), these questions were differentially embedded in a larger set of questions and participant anonymity was maintained (Podsakoff, MacKenzie, Lee, \& Podsakoff, 2012).

\section{Measures}

\section{Intention to initiate negotiation}

There were four dependent variables - one for each of the three phases of initiation as well as an overall measure. We measured the three distinct phases of negotiation initiation (i.e., engaging but not making the first offer, engaging and making the first offer, engaging and optimizing the first offer) based on the alternative that a participant ranked first (most preferred alternative). Each participant was scored for engaging ( 0 for alternative a, above; 1 for alternative $b$, c, or $d)$, requesting $(0$ for alternative $a$ or $b$; 1 for alternative $\mathrm{c}$ or $\mathrm{d}$ ), and optimizing ( 0 for alternative $\mathrm{a}, \mathrm{b}$, or $\mathrm{c} ; 1$ for alternative $\mathrm{d}$ ). Overall initiation - the fourth dependent variable - was the sum of these three values, a number from zero for nonengagement to three for engagement, requesting, and optimizing (one point each for engaging, requesting, and optimizing). 


\section{Bargaining power}

In terms of independent variables, the relative bargaining power of participants varied across the two scenarios, with participants in a low-power position in the salary negotiation (no alternatives, time deadline, counterpart a future supervisor/superior with a BATNA) and a high-power position for the work assignment involving a freelancer (in-house alternative, counterpart with no apparent alternatives). Differences in relative power for these two scenarios were examined empirically by Kapoutsis, Volkema, and Nikolopoulos (2013), with each scenario rated using a scale from 0 (my counterpart has all the power) to 100 (I have all the power). The results confirmed that participants perceived significantly higher power in the work assignment scenario than in the salary scenario $(\mathrm{p}<.01)$. Thus, relative power was coded as a binary value - high or low.

\section{Individualism-collectivism}

The degree of individualism-collectivism was based on House et al.'s (2004) measures for institutional collectivism (i.e., the degree to which individuals are or should be encouraged by institutions to be integrated into broader entities with harmony and cooperation as paramount principles at the expense of autonomy and individual freedom).These include societal-level institutional collectivism practices, a measure for practices (as is) and societal-level institutional collectivism values, a measure for values (should be). The variables are each based on two questions, measured using 7point Likert scales (the higher the number, the higher the perceived institutional collectivism).

\section{Analysis}

Because participants responded to two scenarios, each describing a different condition of bargaining power (low vs. high), we pooled the data and analyzed them in panel form, with the decision to initiate negotiations for each scenario as the unit of analysis. Therefore, the total number of observations was 244 (122 participants x 2 decisions). To examine the association of institutional collectivism to overall initiation we conducted a repeated measures multiple regression using a generalized estimating equations (GEE) approach (Liang \& Zeger, 1986) in a two-stage model (the main effects followed by interaction terms), with overall initiation treated as a continuous variable. GEE is an extension of the general linear model which allows the analysis of dependent variables with non-normal distributions and corrects the estimates for potential within-subject correlation of errors (within subject variability) between repeated decisions (Ballinger, 2004). As a participant's decision in one scenario may affect the decision in the other, each set of repeated observations should deal with autocorrelation as a result of the dependence between decisions. Then, we considered the three binary dependent variables which pertain to the different phases of the initiation process (i.e., engaging, optimizing, requesting) as repeated observations of the same participant. For this reason, we analyzed the data using repeated measures logistic regressions complemented with a generalized estimating equations (GEE) approach for each phase of the initiation process, specifying an exchangeable correlation structure (i.e., observations clustered within respondents without considering order) in all sets of dependent variables. As gender (Bear, 2011; Bowles et al., 2007; Small et al., 2007) and age (Volkema \& Fleck, 2012) had been found in previous studies to relate to initiation behavior, they were controlled for in this study.

\section{Results}

The descriptive statistics and correlations among the control, independent, and dependent variables are shown in Table 1. Results of the GEE analyses for the overall initiation measure, as well as for each independent phase (i.e., engaging, requesting, optimizing), including the parameter estimates, standard errors (SE), and Z values, are presented in Table 2. The baseline model (Model 1), which includes only the main effects, indicates that bargaining power significantly impacts the intention to initiate negotiations (overall measure of initiation), as the mean level of initiation was more than a 
single unit greater in the high-power situation than the low-power situation (2.34 and 1.18, respectively; Wald $\left.\chi^{2}=122.41, \mathrm{df}=1, \mathrm{p}<.01\right)$. This is consistent with Hypothesis 1 . Furthermore, bargaining power influenced participants' intentions pertaining to making a request (Wald $\chi^{2}=81.74, \mathrm{df}=1, \mathrm{p}<.01$ ) and to optimizing a request (Wald $\chi^{2}=50.35, \mathrm{df}=1, \mathrm{p}<.01$ ). However, bargaining power was not found to be significantly related to the act of engaging a counterpart (Wald $\chi^{2}=0.89, \mathrm{df}=1, \mathrm{p}>.10$ ). In more detail, for the scenario describing the low bargaining power condition, $90.2 \%$ of the participants decided that they would engage negotiations, $17.2 \%$ would make a sub-optimal request, and $10.7 \%$ would optimize their request. In contrast, in the high power scenario, $93.4 \%$ would chose to engage, $82.0 \%$ would make the sub-optimal request, and $59.0 \%$ would optimize the request.

Table 1

\section{Descriptive Statistics and Correlations}

\begin{tabular}{lllllllllll}
\hline $\mathrm{M}$ & $\mathrm{SD}$ & 1 & 2 & 3 & 4 & 5 & 6 & 7 & 8
\end{tabular}

\section{Controls}

1. Gender $(0=$ Male; $1=$ Female $) \quad 0.36 \quad 0.48$

$\begin{array}{lllll}\text { 2. Age } & 38.13 & 10.69 & -.08\end{array}$

Independent Variables

\begin{tabular}{lccccccc}
\hline 3. Power $(0=$ Low; $1=$ High $)$ & - & - & - & - & & \\
4. Institutional Collectivism Values & 5.37 & 1.04 & $.15^{*}$ & -.07 & - & \\
5. Institutional Collectivism & 3.44 & 1.08 & -.06 & .03 & - & $-.17^{* *}$
\end{tabular}

Practices

Dependent Variables

\begin{tabular}{lllllllllllll}
\hline 6. Engage $(0=$ No; $1=$ Yes $)$ & 0.92 & 0.28 & .07 & -.05 & .06 & $-.14 *$ & -.04 & & \\
7. Request $(0=$ No; $1=$ Yes $)$ & 0.50 & 0.50 & .06 & -.01 & $.65^{* *}$ & -.03 & -.04 & $.30 * *$ & \\
8. Optimize $(0=$ No; $1=$ Yes $)$ & 0.35 & 0.48 & -.08 & -.02 & $.51 * *$ & -.06 & $-.12 \dagger$ & $.22 * *$ & $.74 * *$ \\
9. Overall Initiation $(0-3)$ & 1.76 & 1.02 & .01 & -.03 & $.57 * *$ & -.08 & -.09 & $.52 * *$ & $.91 * *$ & $.89 * *$ \\
\hline
\end{tabular}

Note. $\mathrm{N}=244 ; \dagger \mathrm{p}<.10,{ }^{*} \mathrm{p}<.05, * * \mathrm{p}<.01$.

Table 2

Results of GEE Regression Models of the Impact of Power, Institutional Collectivism Practices and Values on Negotiation Initiation

\begin{tabular}{|c|c|c|c|c|c|c|c|c|}
\hline \multirow[t]{2}{*}{ Variables } & \multicolumn{2}{|l|}{ Engage $^{a}$} & \multicolumn{2}{|l|}{ Request $^{\mathrm{a}}$} & \multicolumn{2}{|c|}{ Optimize request ${ }^{\mathrm{a}}$} & \multicolumn{2}{|c|}{ Overall initiation } \\
\hline & Model 1 & Model 2 & Model 1 & Model 2 & Model 1 & Model 2 & Model 1 & Model 2 \\
\hline $\begin{array}{l}\text { Gender } \\
(1=\text { Male; } 2= \\
\text { Female })\end{array}$ & $0.76(0.54)$ & $0.77(0.54)$ & $0.44(0.35)$ & $0.47(0.36)$ & $-0.52(0.34)$ & $-0.53(0.36)$ & $0.03(0.11)$ & $0.03(0.11)$ \\
\hline Age & $-0.22(0.02)$ & $-0.02(0.02)$ & $0.00(0.01)$ & $0.00(0.01)$ & $-0.01(0.01)$ & $0.01(0.02)$ & $0.00(0.00)$ & $0.00(0.00)$ \\
\hline $\begin{array}{l}\text { Power } \\
(0=\text { Low; } 1= \\
\text { High })\end{array}$ & $0.46(0.49)$ & $-0.29(3.76)$ & $3.14(0.35)^{* *}$ & $5.04(2.45)^{* *}$ & $2.61(0.37)^{* *}$ & $7.182(2.92)^{*}$ & $1.16(0.11)^{* *}$ & $2.25(0.71)^{* *}$ \\
\hline $\begin{array}{l}\text { Institutional } \\
\text { collectivism } \\
\text { practices (ICP) }\end{array}$ & $-0.22(0.22)$ & $-0.08(0.25)$ & $-0.15(0.19)$ & $0.17(0.25)$ & $-0.39(0.15)^{*}$ & $0.13(0.26)$ & $-0.10(0.05) \dagger$ & $0.03(0.06)$ \\
\hline
\end{tabular}


Table 2 (continued)

\begin{tabular}{|c|c|c|c|c|c|c|c|c|}
\hline \multirow[t]{2}{*}{ Variables } & \multicolumn{2}{|l|}{ Engage $^{a}$} & \multicolumn{2}{|l|}{ Request $^{\mathrm{a}}$} & \multicolumn{2}{|c|}{ Optimize request ${ }^{\mathrm{a}}$} & \multicolumn{2}{|c|}{ Overall initiation } \\
\hline & Model 1 & Model 2 & Model 1 & Model 2 & Model 1 & Model 2 & Model 1 & Model 2 \\
\hline $\begin{array}{l}\text { Institutional } \\
\text { collectivism } \\
\text { values (ICV) }\end{array}$ & $-0.70(0.28)^{*}$ & $-0.84(0.38)^{*}$ & $-0.17(0.16)$ & $-0.21(0.26)$ & $-0.21(0.16)$ & $0.03(0.36)$ & $-0.10(0.06) \dagger$ & $-0.08(0.08)$ \\
\hline ICP x Power & & $-0.31(0.55)$ & & $-0.63(0.34) \dagger$ & & $-0.76(0.34)^{*}$ & & $-0.26(0.11)^{*}$ \\
\hline ICV x Power & & $0.32(0.45)$ & & $0.07(0.34)$ & & $-0.37(0.41)$ & & $-0.04(0.10)$ \\
\hline
\end{tabular}

Note. ${ }^{\mathrm{a}}$ Logistic regression with GEE; ${ }^{\mathrm{b}}$ Multiple linear regression with GEE.

$\dagger \mathrm{p}<.10, * \mathrm{p}<.05, * * \mathrm{p}<.01 ; \mathrm{N}=244$; Unstandardized parameter estimates are reported with robust standard errors in parenthesis

In addition to bargaining power, institutional collectivism values was marginally related to overall initiation and significantly related to the engaging decision, consistent with Hypothesis 2 . As expected, the lower an individual's collectivist values (higher the individualist values), the less (more) likely he/she would be to initiate overall. Likewise, the lower an individual's collectivist values (higher the individualist values), the less (more) likely they would be to engage a counterpart without making a specific request.

For overall initiation, the result was the same for institutional collectivism practices. However, of the three initiation phases, only optimizing was significant: the lower an individual's collectivist values (higher the individualist values), the less (more) likely he/she would be to optimize a request. Both results were consistent with Hypothesis 2.

As reported in Model 2 of Table 2, the interaction of power and institutional collectivism practices had a significant effect on the intention to initiate negotiations, particularly with reference to the requesting (marginally significant) and optimizing phases. To visualize the interaction, we split the continuous scores for institutional collectivism practices based on their median to create meaningful categories (individualists and collectivists). We then plotted overall initiation for individualists vs. collectivists at low vs. high power. As shown in Figure 1, individualists, compared to collectivists, had a higher propensity to initiate negotiations, but only when relative bargaining power was high, consistent with Hypothesis 3.

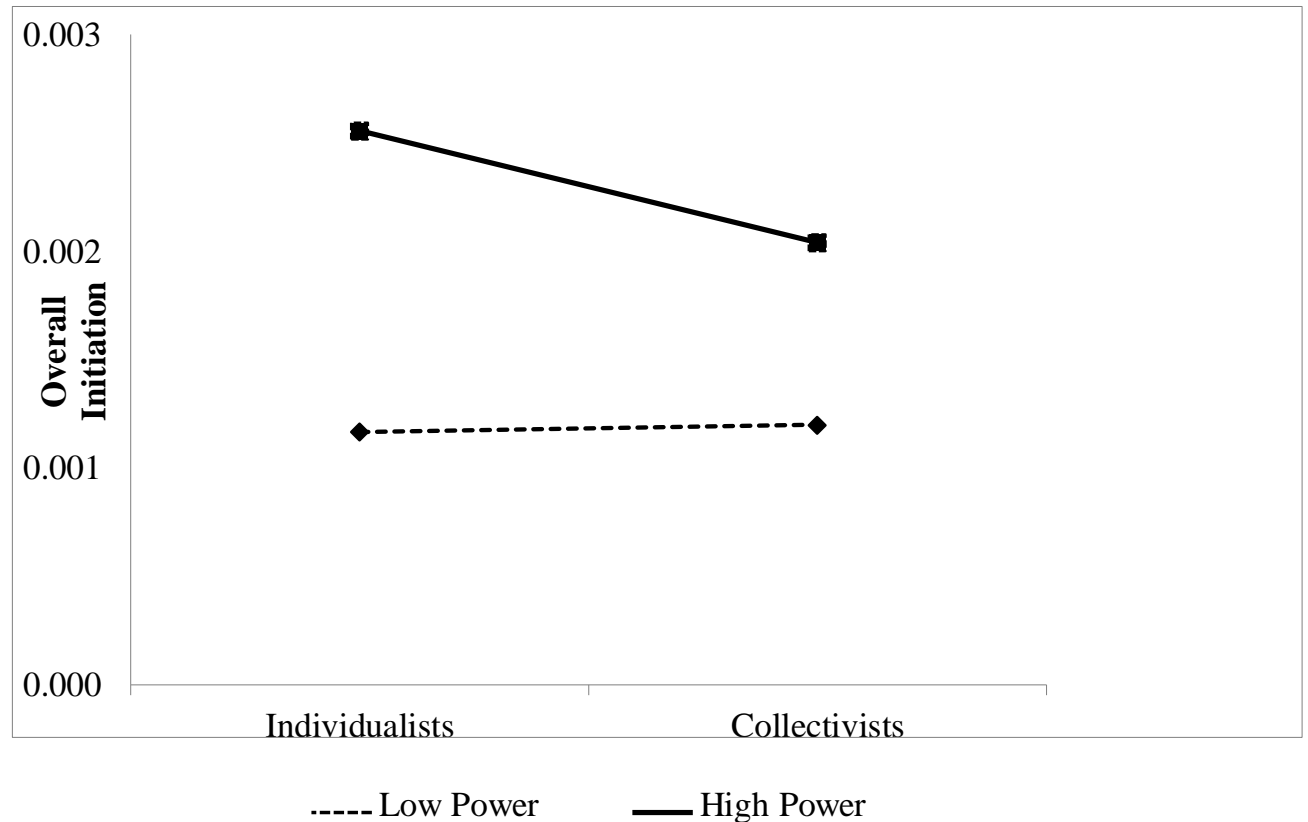

Figure 1. The Impact of Institutional Collectivism Practices (Individualists vs. Collectivists) on Overall Initiation at Low and High Levels of Bargaining Power 
With respect to the three phases of initiation, there were significant results for requesting and optimizing. To visualize the interaction related to requesting and optimizing intentions, we developed plots depicting the percentage of individualists vs. collectivists who decided to make a request or optimize the request dependent on low vs. high bargaining power (splitting the continuous scores for institutional collectivism practices into two categories based on their median). The figures show that individuals high on bargaining power tend to report requesting (Figure 2) and optimizing (Figure 3) decisions more frequently, compared to those low on relative bargaining power. When relative bargaining power is high, individualists are more likely than collectivists to make a request (Pearson $\left.\chi^{2}=10.14, d f=1, p<.01\right)$. Antithetically, when bargaining power is low, whether someone is a individualist or collectivist in practice is immaterial. A similar pattern was found with regard to optimizing: individualists with high relative bargaining power were more likely to optimize than were collectivists with high bargaining power (Pearson $\chi^{2}=5.69, d f=1, p<.05$ ). These results were consistent with Hypothesis 3.

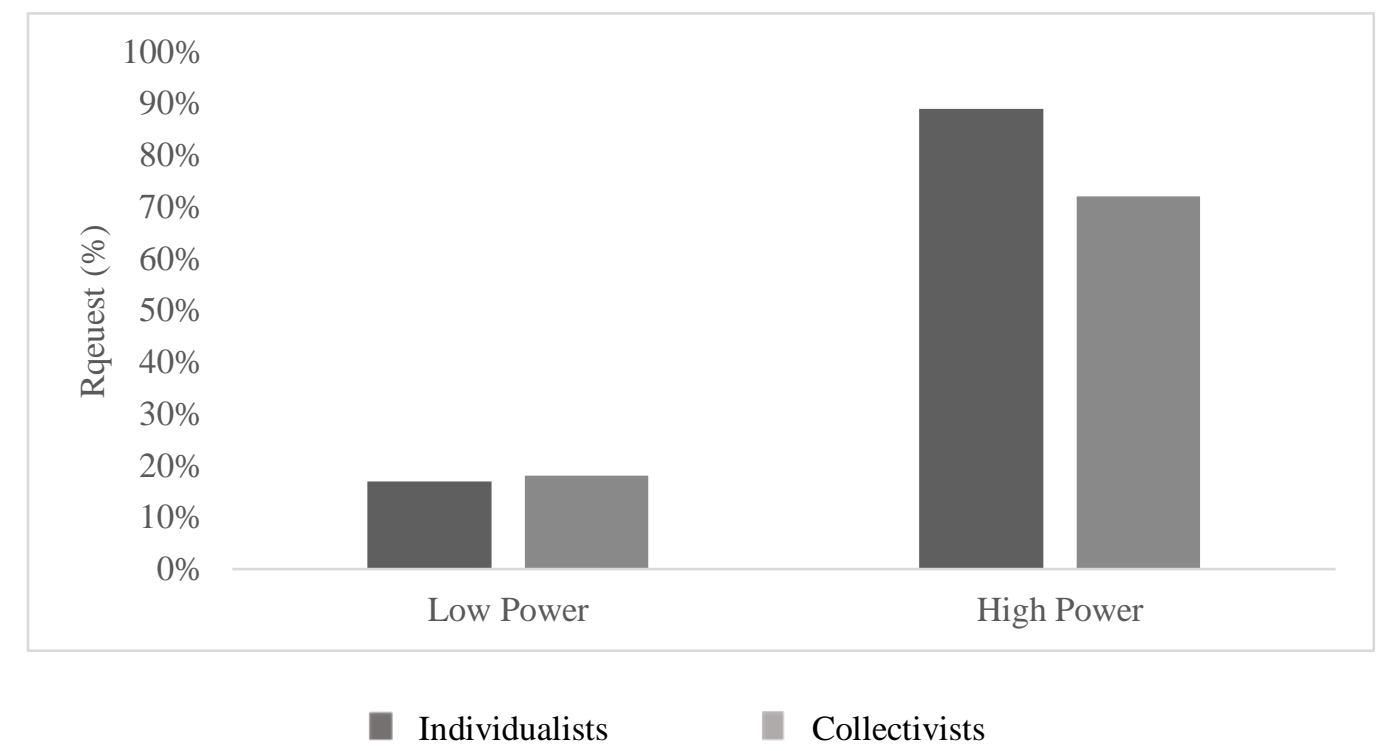

Figure 2. The Impact of Societal-level Institutional Collectivism Practices (Individualists vs. Collectivists) on Requesting at Low and High Levels of Bargaining Power

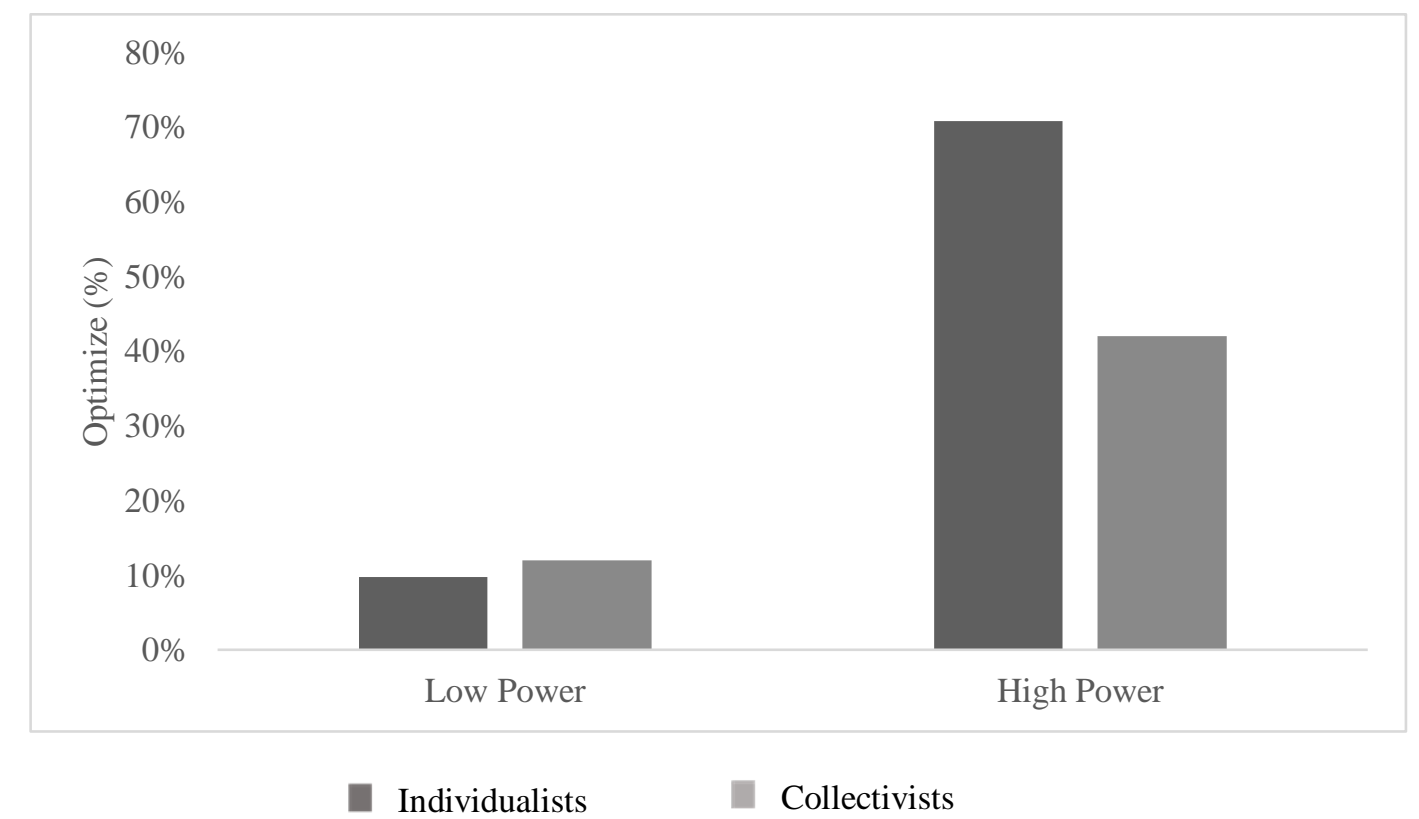

Figure 3. The Impact of Institutional Collectivism Practices (Individualists vs. Collectivists) on Optimizing a Request at Low and High Levels of Bargaining Power 


\section{Discussion and Conclusions}

Business is about negotiating, whether it be with potential customers/clients, suppliers, advertisers, manufacturers, distributors, or investors. And when an individual chooses not to initiate a negotiation, the benefits of this process are at minimum delayed and often lost for one if not all parties. Although often overlooked in early negotiation models and studies, the initiation stage has become recognized in recent years as critical to the negotiation process and business success (Bear, 2011; Kong et al., 2011; Miles, 2010).

In this study we argued that an omnipresent situational factor (i.e. relative bargaining power, Hypothesis 1) and culture (i.e., institutional collectivism values and practices, Hypothesis 2) would influence individuals' intentions to initiate negotiations, such that individuals who have more bargaining power and view societal institutions (i.e., how distribution of resources and actions are encouraged and rewarded) via an individualistic lens would have a higher likelihood to initiate negotiations (overall initiation, and engaging, requesting, and optimizing). Further, we argued that institutional collectivism would moderate the impact of bargaining power on negotiation initiation with individualists being more assertive when they are in a more powerful position (Hypothesis 3). The results generally supported these arguments, since we found significant main effects for power and institutional collectivism on the intention to initiate negotiations, as well as significant interaction effects of institutional collectivism and bargaining power.

\section{Implications for theory development}

With regard to relative bargaining power and institutional collectivism, this study suggests firstand-foremost a strong and consistent effect of relative bargaining power on initiation behavior (with the exception of the intent to simply engage negotiations without making any specific request). In social settings, power is a measure of one's capacity to influence others, generally through perceived control over valued resources (Gruenfeld, Inesi, Magee, \& Galinsky, 2008). Power is often viewed in relative terms (i.e., based on the amount of influence that each party is thought to have over the other) (Brauer \& Bourhis, 2006) and is a dynamic construct, grounded in perceptions of a number of factors, including goal salience, resources/alternatives, time constraints, role expectations, etc. (Horton, 2003; Smith, Houghton, Hood, \& Ryman, 2006). Because of the high degree of uncertainty typically associated with negotiating, power often serves as a coping mechanism. That is, individuals will seek to project a relative power advantage as a means of dealing with their lack of information about a counterpart's expectations, alternatives, honesty, etc.

As Keltner et al. (2003) argue, power can influence an individual's behavioral approach system (BAS) as well as behavioral inhibition system (BIS), both of which can affect the initiation process. The former involves environmental scanning in search of rewards (or goal/task achievement, in the case of negotiation), while the latter alerts an individual to potential risks of action (e.g., embarrassment) or inaction (e.g., goal/task failure). According to prospect theory, individuals will often be influenced more by potential risks or losses than by gains (Tversky \& Kahneman, 1981).

Our results are largely aligned with these theoretical predictions since we found that those who have more bargaining power have almost four and six times greater probability to make a request or optimize this request, respectively. Despite its strong impact on requesting and optimizing, relative bargaining power was found to be unrelated to the engaging option since the majority of respondents (>90\%) in both scenarios reported a willingness to engage their counterparts. This can be attributed to the fact that engaging may be perceived as a risk-free option. People, irrespective of their relative power, may choose to engage a discussion with their counterparts without making any particular request in order to gain more information that could restore power balance or to let the other party improve the offer using engaging as a mild means of expressing dissatisfaction with the current deal. 
This study also indicates that the inability of bargaining power to explain simple engaging intentions in a negotiation can be offset by institutional collectivism values. We found that the likelihood of choosing to engage negotiations without making any first offer was higher for individuals low on institutional collectivism values (individualists). Such findings are consistent with theory and prediction. Individualists, more concerned with individual rights, achievement, and recognition, often viewing negotiations from a distributive (win-lose) perspective, are distinct in their value system from collectivists, whose central interest is the social unit (family, community, etc.). As a consequence, collectivists are less likely to take actions that could threaten their self-face (i.e., self-identity, respect) or the face of others (i.e., a prospective counterpart's public identity). In many situations, making a request/demand and, to a greater extent, seeking to optimize that request would appear to run counter to a collectivist's concerns for face and harmony.

Our results also indicate that when individuals appraise the society as individualistic in practice, they initiate negotiations by making a request (optimal or sub-optimal). The act of engagement for collectivists would appear to be nonthreatening to self-face and the face of a counterpart, an act which need involve minimal if any conversation. Cumulatively, such findings suggest that individuals' construals about societal values may motivate them to engage in a negotiation, but the assessment of how collectivist or individualist a society is in practice will push them towards optimizing potential requests.

Since these business scenarios represented situations that participants could realistically expect to encounter, if they had not already, it is understandable that they might be guided by how their peers would behave rather than an idyllic set of values; collectivism practices are more immediate and tangible. Thus, the more individualist the participant (i.e., oriented towards individual rights, achievement, and recognition), the greater the likelihood of overcoming any social inertia in order to initiate actions expected to achieve one's objectives. In contrast, the more collectivist the participant, the more risk is undertaken to the status quo or harmony of one's social unit (family, community, coworkers, etc.) through initiation, particularly when optimizing a request.

As there was a tendency towards requesting even among collectivists, this requires further investigation, including a more in-depth understanding of the ways in which requests can be made. The choice of medium and the degree of directness (e.g., asking in the form of a question rather than a declaration) could represent mediating factors. In terms of the latter, for example, Li, Tost, and WadeBenzoni (2007) contend that individualists are more likely to communicate directly, while collectivists tend more towards indirect communication. A linguistic examination of forms of requesting during initiation of a negotiation could provide further verification and insights.

The significant finding for the interaction of relative bargaining power and institutional collectivism practices also is worth noting. For individualists with high power, the likelihood to initiate a negotiation by making a first offer is significantly higher than for collectivists with high power (for requesting, from $89 \%$ to $72 \%$; for optimizing, from $71 \%$ to $42 \%$ ), which suggests an attenuation effect of individualism on bargaining power (or suppression effect for collectivists). Thus, individualists seem more emboldened, moving closer to optimizing their requests. This is consistent with the expectation that individualists will use power as necessary to fully achieve their goals (Oishi, Schimmack, Diener, \& Suh, 1998).

\section{Implications for practice}

The finding that relative bargaining power is important to the initiation process is especially important for practitioners, since power is a dynamic construct that can be altered. For example, an individual can change the reality and perception of alternatives for self and/or counterpart through various means, which can influence initiation likelihood. By developing one or more alternatives quickly, though not necessarily with one's primary target, an individual can increase the likelihood of subsequently pursuing initiation with the target counterpart to the fullest phase possible (i.e., requesting and optimizing). 
It is even conceivable that, in the interests of getting an individual to initiate a negotiation, a counterpart could alter the individual's perceptions of dependency. That is, there are circumstances where a counterpart might benefit from facilitating another party in initiating a negotiation with him or her. This could be accomplished in various ways, including by the counterpart suggesting the importance of the individual to the organization, his/her unique perspectives, etc.

Culture, on the other hand, presents a different challenge to negotiators. While there may be benefits to altering one's approach when in another culture (Weiss, 1994), adjusting may not be commonplace or easy (Gelfand \& Brett, 2004). Consequently, it would seem more important to recognize the strengths and challenges that one's own cultural orientation might present as well as the cultural values of one's counterpart. For a collectivist, this means anticipating that an individualist counterpart migght appear more aggressive in his or her approach, feeling comfortable asking, if not optimizing a request. For an individualist, this suggests helping a collectivist - who might sometimes prefer avoidance - to feel more comfortable engaging, if not making a request, and recognizing that those requests may come in an indirect form (Lee et al., 2006). In some cases, these sensitivities might best be handled by an agent from the counterpart's culture.

\section{Limitations and future research}

As with all research, there are caveats in the interpretation and application of this study that must be noted. First, while we employed two different scenarios, there would be value in replicating the study with other foci/issues. The role of the participants in the two scenarios was, arguably, to promote selfinterests, not to do a favor for the other party. There are conceivably situations where a person might feel inhibited about initiating a negotiation for which the primary purpose is benefiting a counterpart (e.g., offering to take the blame for a failed decision). Thus, a broader set of negotiating scenarios might be considered in future research. Second, our manipulation of bargaining power was primarily based on perceived alternatives available to the parties. While resource dependency theory supports alternatives as an important element of power, other sources of power and varying degrees of power (e.g., number of alternatives available to each party) might be investigated. Third, we employed House et al.'s (2004) measures of individualism-collectivism. As with many dimensions of culture, there is no single, agreedupon (standard) measure that currently exists (Earley \& Gibson, 1998). It might be useful to consider other measures of individualism-collectivism, as a means of verifying the findings of Hypothesis 2. Moreover, we chose a sample of Brazilian professionals to participate in this study, in part due to their individualist-collectivist composition. Researchers might seek to include individuals from other country cultures in future studies. Finally, endogeneity is a concern with all empirical research, particularly within the social sciences where other variables could be affecting both independent and dependent measures, and where simultaneity among variables could exist. Endogeneity can be addressed through an experimental design (treatment, control), although the individualism-collectivism variable in this study does not lend itself to manipulation. And while relative bargaining power was suggested as influencing initiation behavior, it is possible that the willingness to initiate is affecting one's sense of power.

\section{Final Remarks}

For many years, the primary focus of conflict and negotiation researchers was the relationship between tactics and outcome. It was assumed that the parties to a negotiation were already at the bargaining table. More recently, initiation has been recognized as an important stage of the negotiation process. As with many processes (e.g., planning, problem solving, group/team development), the early stages are often critical to the viability and success of succeeding stages. In the case of negotiation, failure to initiate can result in immediate and long-term losses for all parties. The studies reported herein are among the first to move past demographic factors (e.g., gender) to examine the influence of context/situation and culture on initiation. The more we can learn about these factors, the more effective 
individuals can become in initiating negotiations as well as assisting others (including potential counterparts) in this process.

\section{References}

Adair, W. L., \& Brett, J. M. (2004). Culture and negotiation processes. In M. J. Gelfand \& J. M. Brett (Eds.), The handbook of culture and negotiation (pp. 158-176). Stanford, CA: Stanford University Press.

Ames, D. R. (2008). Assertiveness expectancies: how hard people push depends on the consequences they predict. Journal of Personality and Social Psychology, 95(6), 1541-1557. http://dx.doi.org/10.1037/a0013334

Bacharach, S. B., \& Lawler, E. J. (1981). Bargaining: power, tactics, and outcomes. San Francisco, CA: Jossey-Bass.

Ballinger, G. A. (2004). Using generalized estimating equations for longitudinal data analysis. Organizational Research Methods, 7(2), 127-150. http://dx.doi.org/10.1177/1094428104263672

Bazerman, M. H., Curhan, J. R., Moore, D. A., \& Valley, K. L. (2000). Negotiation. Annual Review of Psychology, 51(1), 279-314. http://dx.doi.org/10.1146/annurev.psych.51.1.279

Bear, J. (2011). "Passing the buck": Incongruence between gender role and topic leads to avoidance of negotiation. Negotiation and Conflict Management Research, 4(1), 47-72. http://dx.doi.org/10.2139/ssrn.1611835

Bodey, K., \& Grace, D. (2007). Contrasting "complainers" with "non-complainers" on attitude toward complaining, propensity to complain, and key personality characteristics: a nomological look. Psychology \& Marketing, 24(7), 579-594. http://dx.doi.org/10.1002/mar.2017

Bowles, H. R., Babcock, L., \& Lai, L. (2007). Social incentives for gender differences in the propensity to initiate negotiations: sometimes it does hurt to ask. Organizational Behavior and Human Decision Processes, 103(1), 84-103. http://dx.doi.org/10.1016/j.obhdp.2006.09.001

Brauer, M., \& Bourhis, R. Y. (2006). Social power. European Journal of Social Psychology, 36(4), 601 616. http://dx.doi.org/10.1002/ejsp.355

Chebat, J.-C., Davidow, M., \& Codjovi, I. (2005). Silent voices: why some dissatisfied consumers fail to complain. Journal of Service Research, 7(4), 328342. http://dx.doi.org/10.1177/1094670504273965

Chelminski, P., \& Coulter, R. A. (2007). The effects of cultural individualism and self-confidence on propensity to voice: from theory to measurement to practice. Journal of International Marketing, 15(4), 94-118. http://dx.doi.org/10.1509/jimk.15.4.94

Curhan, J. R., Elfenbein, H. A., \& Xu, H. (2006). What do people value when they negotiate? Mapping the domain of subjective value in negotiation. Journal of Personality and Social Psychology, 91(3), 493-512. http://dx.doi.org/10.1037/0022-3514.91.3.493

De Dreu, C. K. W., Giebels, E., \& Van de Vliert, E. (1998). Social motives and trust in integrative negotiation: the disruptive effects of punitive capability. Journal of Applied Psychology, 83(3), 408-422. http://dx.doi.org/10.1037/0021-9010.83.3.408 
Earley, P. C., \& Gibson, C. B. (1998). Taking stock in our progress on individualism-collectivism: 100 years of solidarity and community. Journal of Management, 24(3), 265-304. http://dx.doi.org/10.1177/014920639802400302

Fisher, R., \& Ury, W. (1981). Getting to yes: negotiating agreement without giving in. Boston, MA: Houghton Mifflin.

French, J., \& Raven, B. (1959). The bases of social power. In D. Cartwright (Ed.), Studies in social power (pp. 150-167). Ann Arbor, MI: Institute for Social Research.

Furst, S. A. Reeves, M., Rosen, B., \& Blackburn, R. S. (2004). Managing the life cycle of virtual teams. Academy of Management Executive, 18(2), 6-20. http://dx.doi.org/10.5465/AME.2004.13837468

Galinsky, A. D., Gruenfeld, D. H, \& Magee, J. C. (2003). From power to action. Journal of Personality and Social Psychology, 85(3), 453-466. http://dx.doi.org/10.1037/0022-3514.85.3.453

Galinsky, A. D., Magee, J. C., Inesi, M. E., \& Gruenfeld, D. H. (2006). Power and perspectives not taken. Psychological Science, 17(12), 1068-1074. http://dx.doi.org/10.1111/j.14679280.2006.01824.x

Gelfand, M. J., \& Brett, J. M. (2004). The handbook of negotiation and culture. Stanford, CA: Stanford University Press.

Gelfand, M. J., \& Christakopoulou, S. (1999). Culture and negotiator cognition: judgment accuracy and negotiation processes in individualistic and collectivistic cultures. Organization Behavior and Human Decision Processes, 79(3), 248-269. http://dx.doi.org/10.1006/obhd.1999.2845

Gelfand, M. J., \& Realo, A. (1999). Individualism-collectivism and accountability in intergroup negotiation. Journal of Applied Psychology, 84(5), 721-736. http://dx.doi.org/10.1037/00219010.84.5.7.21

Gerhart, B., \& Rynes, S. (1991). Determinants and consequences of salary negotiations by male and female MBA graduates. Journal of Applied Psychology, 76(2), 256-262.

Gruenfeld, D. H., Inesi, M. E., Magee, J. C., \& Galinsky, A. D. (2008). Power and the objectification of social targets. Journal of Personality and Social Psychology, 95(1), 111-127. http://dx.doi.org/10.1037/0022-3514.95.1.111

Harvey, M. G., Buckley, M. R., Novicevic, M. M., \& Halbesleben, J. R. B. (2004). The Abilene paradox after thirty years: a global perspective. Organizational Dynamics, 33(2), 215-226. http://dx.doi.org/10.1016/j.orgdyn.2004.01.008

Hofstede, G. H. (1997). Cultures and organizations: software of the mind. New York: McGraw-Hill.

Hofstede, G. H. (2001). Cultures consequences: comparing values, behaviors, institutions, and organizations across nations ( 2 nd ed.). Thousand Oaks, CA: Sage.

Horton, K. S. (2003). Strategy, practice, and the dynamics of power. Journal of Business Research, 56(2), 121-126. http://dx.doi.org/10.1016/S0148-2963(01)00284-3

House, R. J., Hanges, P. J., Javidan, M., Dorfman, P. W., \& Gupta, V. (2004). Culture, leadership, and organizations: the GLOBE study of 62 societies. Thousand Oaks, CA: Sage.

Huppertz, J. H. (2003). An effort model of first-stage complaining behavior. Journal of Consumer Satisfaction, Dissatisfaction and Complaining Behavior, 16(2), 132-144. 
Kapoutsis, I., Volkema, R. J., \& Nikolopoulos, A. G. (2013). Initiating negotiation: the role of Machiavellianism, risk propensity, bargaining power. Group Decision and Negotiation, 22(6), 1081-1101. http://dx.doi.org/10.1007/s10726-012-9306-6

Keltner, D., Gruenfeld, D. H., \& Anderson, C. (2003). Power, approach, and inhibition. Psychological Review, 110(2), 265-284. http://dx.doi.org/10.1037/0033-295X.110.2.265

Kong, D. T., Tuncel, E., \& McLean Parks, J. (2011). Anticipating happiness in a future negotiation: anticipated happiness, propensity to initiate a negotiation, and individual outcomes. Negotiation and Conflict Management Review, 4(3), 219-247. http://dx.doi.org/10.1111/j.17504716.2011.00081.x

Kramer, R. M., \& Messick, D. M. (1995). Negotiation as a social process: new trends in theory and research. Thousand Oaks, CA: Sage.

Lax, D. A., \& Sebenius, J. K. (1986). The manager as negotiator. New York: The Free Press.

Lee, K., Yang, G., \& Graham, J. L. (2006). Tension and trust in international business negotiations: American executives negotiating with Chinese executives. Journal of International Business Studies, 37(5), 623-641. http://dx.doi.org/10.1057/palgrave.jibs.8400215

Lewicki, R. J., Barry, B., \& Saunders, D. M. (2010). Negotiation (6th ed.). Boston, MA: McGrawHill/Irwin.

Lewicki, R. J., Weiss, S. E., \& Lewin, D. (1992). Models of conflict, negotiation and third party intervention: a review and synthesis. Journal of Organizational Behavior, 13(3), 209-252. http://dx.doi.org/10.1002/job.4030130303

Li, M., Tost, L. P., \& Wade-Benzoni, K. (2007). The dynamic interaction of context and negotiator effects: a review and commentary on current and emerging areas in negotiation. International Journal of Conflict Management, 18(3), 222-259. http://dx.doi.org/10.1108/10444060710825981

Liang, K.-Y., \& Zeger, S. L. (1986). Longitudinal data analysis using generalized linear models. Biometrika, 73(1), 13-22. http://dx.doi.org/10.2307/2336267

Liu, B. S.-C., Furrer, O., \& Sudharshan, D. (2001). The relationships between culture and behavioral intentions toward services. Journal of Service Research, 4(2), 118129. http://dx.doi.org/10.1177/109467050142004

Magee, J. C., Galinsky, A. D., \& Gruenfeld, D. H. (2007). Power, propensity to negotiate, and moving first in competitive interactions. Personality and Social Psychology Bulletin, 33(2), 200-212. http://dx.doi.org/10.1177/0146167206294413

Miles, E. W. (2010). The role of face in the decision not to negotiate. International Journal of Conflict Management, 21(4), 400-414. http://dx.doi.org/10.1108/10444061011079949

Miles, E. W., \& Clenney, E. F. (2012). Extremely difficult negotiator goals: do they follow the predictions of goal-setting theory? Organizational Behavior and Human Decision Processes, 118(2), 108-115. http://dx.doi.org/10.1016/j.obhdp.2012.02.001

Mintzberg, H. (1973). The nature of managerial work. New York: Harper \& Row.

Mitroff, I. I., \& Silver, A. (2009). Dirty rotten strategies, how we trick ourselves and others into solving the wrong problems precisely. Palo Alto, CA: Stanford University Press.

Mnookin, R. H., \& Susskind, L. E. (1999). Negotiating on behalf of others: advice to lawyers, business executives, sports agents, diplomats, politicians, and everybody else. Thousand Oaks, CA: Sage. 
Morrison, E. W., Chen, Y.-R., \& Salgado, S. R. (2004). Cultural differences in newcomer feedback seeking: a comparison of the United States and Hong Kong. Applied Psychology: An International Review, 53(1), 1-22. http://dx.doi.org/10.1111/j.1464-0597.2004.00158.x

Nutt, P. C. (1984). Planning process archetypes and their effectiveness. Decision Sciences, 15(2), 221238. http://dx.doi.org/10.1111/j.1540-5915.1984.tb01210.x

Oetzel, J., Garcia, A. J., \& Ting-Toomey, S. (2008). An analysis of the relationships among face concerns and facework behaviors in perceived conflict situations: a four-culture investigation. International Journal of Conflict Management, 19(4), 382-403. http://dx.doi.org/10.1108/10444060810909310

Oetzel, J., \& Ting-Toomey, S. (2003). Face concerns in interpersonal conflict: a cross-cultural empirical test of the face negotiation theory. Communication Research, 30(6), 599-624. http://dx.doi.org/10.1177/0093650203257841

Oishi, S., Schimmack, U., Diener, E., \& Suh, E. M. (1998). The measurement of values and individualism-collectivism. Personality and Social Psychology Bulletin, 24(11), 1177-1189. http://dx.doi.org/10.1177/01461672982411005

Pfeffer, J. (1983). Organizations and organization theory. Boston, MA: Pitman.

Podsakoff, P. M., MacKenzie, S. B., Lee, J.-Y., \& Podsakoff, N. P. (2012). Sources of method bias in social science research and recommendations on how to control it. Annual Review of Psychology, 63, 539-569. http://dx.doi.org/10.1146/annurev-psych-120710-100452

Requejo, W. H., \& Graham, J. L. (2008). Global negotiation: the new rules. New York: Palgrave Macmillan.

Salacuse, J. W. (1999). Intercultural negotiation in international business. Group Decision and Negotiation, 8(3), 217-236. http://dx.doi.org/10.1023/A:1008660330550

Schwartz, S. H. (1992). Universals in the content and structure of values: theoretical advances and empirical tests in 20 countries. In M. P. Zanna (Ed.), Advances in experimental social psychology (Vol. 25, pp. 1-65). San Diego and London: Academic Press.

Small, D. A., Gelfand, M., Babcock, L., \& Gettman, H. (2007). Who goes to the bargaining table? The influence of gender and framing on initiation of negotiation. Journal of Personality and Social Psychology, 93(4), 600-613. http://dx.doi.org/10.1037/0022-3514.93.4.600

Smith, A., Houghton, S. M., Hood, J. N., \& Ryman, J. A. (2006). Power relationships among top managers: does top management team power distribution matter for organizational performance? Journal of Business Research, 59(5), 622-629. http://dx.doi.org/10.1016/j.jbusres.2005.10.012

Taylor, S. E., Sherman, D. K., Kim, H. S., Jarcho, J., Takagi, K., \& Dunagan, M. S. (2004). Culture and social support: who seeks it and why? Journal of Personality and Social Psychology, 87(3), 354362. http://dx.doi.org/10.1037/0022-3514.87.3.354

Thøgersen, J., Juhl, H., \& Poulsen, C. (2009). Complaining: a function of attitude, personality, and situation. Psychology \& Marketing, 26(8), 760-777. http://dx.doi.org/10.1002/mar.20298

Thompson, L. (2012). The mind and heart of the negotiator (5th ed.). Upper Saddle River, NJ: Pearson Education.

Triandis, H. C. (1989). Cross-cultural studies of individualism and collectivism. In J. Berman (Ed.), Nebraska symposium on motivation (pp. 41-133). Lincoln, NE: University of Nebraska Press. 
Tsay, C.-J., \& Bazerman, M. H. (2009). A decision-making perspective to negotiation: a review of the past and a look into the future. Negotiation Journal, 25(4), 467-480. http://dx.doi.org/10.1111/j.1571-9979.2009.00239.x

Tuckman, B. W. (1965). Development sequence in small groups. Psychological Bulletin, 63(6), 384399. http://dx.doi.org/10.1037/h0022100

Tversky, A., \& Kahneman, D. (1981). The framing of decisions and the psychology of choice. Science, 211(4481), 453-458. http://dx.doi.org/10.1126/science.7455683

Volkema, R. J. (2009). Why Dick and Jane don't ask: getting past initiation barriers in negotiations. Business Horizons, 52(6), 595-604. http://dx.doi.org/10.1016/j.bushor.2009.07.005

Volkema, R. J. (2012). Why people don't ask: understanding initiation behavior in international negotiations. Thunderbird International Business Review, 54(5), 625-637. http://dx.doi.org/10.1002/tie.21489

Volkema, R. J., \& Fleck, D. (2012). Understanding propensity to initiate negotiations: an examination of the effects of culture and personality. International Journal of Conflict Management, 23(3), 266-289. http://dx.doi.org/10.1108/10444061211248976

Volkema, R. J., Kapoutsis, I., \& Nikolopoulos, A. (2013). Initiation behavior in negotiations: the moderating role of motivation on the ability-intentionality relationship. Negotiation and Conflict Management Research, 6(1), 32-48. http://dx.doi.org/10.1111/ncmr.12002

Volkema, R. J., \& Rivers, C. (2012). Beyond frogs and scorpions: a risk-based framework for understanding negotiating counterparts' ethical motivations. Negotiation Journal, 28(4), 379-405. http://dx.doi.org/10.1111/j.1571-9979.2012.00348.x

Weiss, S. E. (1994). Negotiating with 'Romans' - part 2. Sloan Management Review, 35(3), 85-99.

\section{Authors' Profiles}

\section{Roger Volkema}

Rua Marques de São Vicente, 255, Gávea, 22451080, Rio de Janeiro, RJ, Brasil. E-mail: volkema@iag.puc-rio.br

Ilias Kapoutsis

76 Patission Str, Athens 10434, Greece. E-mail: ikapoutsis@aueb.gr

Ana Bon

Rua Marques de São Vicente, 255, Gávea, 22451080, Rio de Janeiro, RJ, Brasil. E-mail: anacarla.bon@ @otmail.com

José Ricardo Almeida

Rua Prof. Aristides Novis, 2, Federação, 40210-630, Salvador, BA, Brasil. E-mail: almeida.jose@ufba.br 


\section{APPENDIX}

Scenario X: Imagine that you are negotiating with a small but growing company about the terms of their job offer to you. The head of the human resources department has informed you that you will need to call and finalize your salary with the owner of the company, but that the previous person in this position had a salary of 72,000 . This figure might be acceptable to you, but it is noticeably below what you know similar people make in similar positions $(90,000-105,000)$. The job is your top choice, but you were expecting a considerably higher salary. You don't know if the company is considering other individuals for this position. You would like to have this decided within the next 2-3 days.

Rank the following four responses in terms of how likely you would be to use them. Give a 1 to the response you would be most likely to use, and a $\underline{4}$ for the response you would be least likely to use.

You wait for the owner to contact you, knowing that the position could go to someone else.

You call the owner and ask him to go into more detail about the position.

You call the owner and ask for a salary of 80,000.

You call the owner and ask for a salary of 105,000.

Scenario Y: Imagine that you are working in a consulting firm and are preparing a series of company profiles for an important client. A freelance graphics artist has been taking the raw text and figures you have been sending by e-mail and creating the presentation-ready profile documents. Each one takes about an hour, and the freelancer charges you $\$ 80$ an hour ( $\$ 80$ per profile). The freelancer sent you what he thought was the final profile and said he was planning to take a few much-needed days off. But you just realized there are 10 more profiles to do. You don't know what happened, or who, if anyone, is to blame, but the e-mail you sent to him with this final batch didn't get through. You have 24 hours before everything needs to be ready. It is possible that your company's internal graphics artists could help, but they are often slow and unreliable.

Rank the following four responses in terms of how likely you would be to use them. Give a 1 to the response you would be most likely to use, and a $\underline{4}$ for the response you would be least likely to use.

You decide not to impose on the freelancer, and you begin to contact your internal graphics department to see if they can help.

You thank the freelancer for his work and tell him you hope he has a good break. You mention that you may have your internal graphics department complete some additional work that needs immediate attention during his absence.

You thank the freelancer for his work and explain the situation to him. You tell him you'd be grateful if he could help out in any way. You offer to pay him for 10 hours $(\$ 800)$ if he could do just five of the 10 profiles (normally 5 hours of work).

You thank the freelancer for his work and explain the situation to him. You tell him that you need the 10 profiles done in the next day and that you'll pay the regular rate $(\$ 800)$. 